\title{
Comparison of three wet-alkaline methods of digestion of biogenic silica in water
}

\author{
GERALD L. KRAUSSE, CLAIRE L. SCHELSKE and CURTISS O. DAVIS* \\ Great Lakes Research Division, University of Michigan, Ann Arbor, U.S.A.
}

SUMMARY. Methods for determination of low levels of biogenic silica $\left(0.2-0.4 \mathrm{mg} \mathrm{SiO}_{2}\right)$ in aqueous samples after digestion with three wetalkaline extraction procedures compared favourably in both precision of replicates and recovery of silica utilized by diatoms in budgeted cultures. Leaching samples with $0.2 \mathrm{M} \mathrm{NaOH}$ for $10-15 \mathrm{~min}$ at $100^{\circ} \mathrm{C}$ was the least time consuming procedure. Also interference from silicate minerals was lower for this method than leaching with either 0.5 or $5 \% \mathrm{Na}_{2} \mathrm{CO}_{3}$ for $2 \mathrm{~h}$ at $85^{\circ} \mathrm{C}$. The use of filters to concentrate samples enables detection of low levels of biogenic silica with colorimetric procedures. Polycarbonate filters are recommended in preference to cellulose acetate or polyvinyl chloride filters for sample collection. Time-course experiments are recommended for establishing digestion times and determining the presence of mineral silicate interference. Wet-alkaline digestion methods are recommended for routine analysis of biogenic silica in suspended matter in preference to infra-red analysis, alkaline fusion and hydrofluoric acid/nitric acid methods.

\section{Introduction}

Silica occurs in water in the soluble, colloidal and particulate forms. In many ecological studies the working definitions are that soluble and colloidal silica pass through a $0.45-\mu \mathrm{m}$ pore size filter and that particulate silica is retained by the filter. In our study, the fraction of interest is the particulate biogenic silica produced by diatoms (Bacillariophyceae) which has been used as an index of diatom abundance (Lehman, 1979). Diatoms have an obligate silica requirement for growth, assimilate orthosilicic acid $\left[\mathrm{Si}(\mathrm{OH})_{4}\right]$ from water and accumulate more than $95 \%$ of

Correspondence: Mr G. L. Krausse, Great Lakes Research Division, University of Michigan, Ann Arbor, Michigan 48109, U.S.A.

*Present address: Tiburon Center for Environmental Studies, San Francisco State University, Box 855 , Tiburon, California 94920, U.S.A. the assimilated silica in frustules as an amorphous polymorph of silica (Werner, 1977).

Recent studies of silica dynamics point to the need for data on biogenic silica to improve understanding of silica cycles in the Great Lakes (Conway et al., 1977; Parker. Conway \& Yaguchi, 1977; Johnson \& Eisenreich, 1979). Historically phytoplankton communities in these systems have been dominated by diatoms (Beeton \& Chandler, 1963; Stoermer, 1978). In Lake Michigan, however, due to accelerated eutrophication associated with increased phosphorus loadings, standing crops of diatoms have become large enough to reduce soluble silica to levels that limit diatom production during summer stratification (Schelske \& Stoermer, 1971), thus allowing blue-green and green algae to replace a large percentage of the diatoms (Conway et al., 1977). The need for understanding silica dynamics is by no means 
limited to the Great Lakes and encompasses other freshwater as well as marine environments (Dugdale, 1972; Wollast. 1974).

This study was initiated to review procedures for analysis of biogenic silica in water and select a procedure that could be adapted for rapid. routine analysis of Great Lakes samples, many

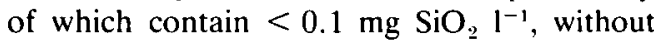
sacrificing precision and accuracy. Also we desired a method that would produce minimum levels of interference from mineral silicates.

The terms biogenic and amorphous silica have been used by different authors to refer to the same substance. We will use biogenic silica throughout this study to indicate biologically incorporated silica, and amorphous silica to designate all non-crystalline silica forms.

\section{Review of methods}

Methods used to quantitatively determine particulate silica (since total and biogenic overlap) in water follow two general approaches; they are either based on structural characteristics or utilize chemical characteristics.

A method based on absorption of infra-red energy by a solid sample was developed by Chester \& Elderfield (1968) to determine the biogenic silica content of deep sea sediments. This technique was applied to freshwater plankton analysis by Bailey-Watts (1976).

Methods that utilize chemical characteristics can be separated into fusion, hydrofluoric acid/ nitric acid and wet-alkaline digestion procedures. Fusion of silica with fluxes such as alkali-borates or alkali-carbonates forms soluble silica salts which can be readily dissolved and analysed colorimetrically. It has been used to determine particulate silica in cultured diatoms (Busby \& Lewin, 1967), and water samples (Golterman, 1969). Fusion is not selective for different forms of silica, hence values obtained by fusion are considered as total silica. Another approach which has been used to determine total particulate silica in water samples utilizes a hydrofluoric and nitric acid digestion of samples collected on cellulose acetate filters followed by silica analysis with an atomic absorption spectrophotometer (Simmons, 1980). With wetalkaline digestion, a heated solution of carbonate or hydroxide readily hydrates and depolymerizes amorphous silica to yield monosilicic acid which can be measured colorimetrically (Tessenow, 1966; Werner, 1966; Hurd, 1973; Paasche, 1973, 1980; Conway et al., 1977; Lawson, Hurd \& Pankratz, 1979). Wet-alkaline extractions appear to leach silica from mineral silicates more slowly than from amorphous silica (McKyes, Sethi \& Young, 1974; Demaster, 1979). There is little information on the amount of interference from nonbiogenic silica in water when using carbonate extractions, and none when using sodium hydroxide extractions.

The infra-red method requires specialized equipment and did not seem well suited for routine processing of samples. Fusion and hydrofluoric acid/nitric acid methods are not selective for amorphous silica so they were not considered for additional study. Wet-alkaline extractions appear to be best suited for our objectives because the digestion product can be easily and rapidly measured with a high degree of sensitivity. They do have the inherent disadvantage of not being completely selective for amorphous silica; however, the magnitude of mineral interference nonetheless can be estimated (McKyes et al., 1974; Demaster, 1979).

\section{Methods and Results}

Three published wet-alkaline digestion methods (Paasche, 1973, 1980; Conway et al., 1977) were compared for accuracy and precision in analysis of biogenic silica in Great Lakes diatom samples, and for their relative efficiency for leaching various mineral silicates. Procedural information for these methods is summarized in Table 1 . Also, using one or more of the listed methods, three filter types, cellulose acetate, polycarbonate and polyvinyl chloride, were investigated for interferences and/or contamination.

\section{Digestion of biogenic silica}

Experiments were conducted on cultures of common Great Lakes diatoms, Diatoma tenue Ag. and Fragilaria crotonensis Kitt, and a natural phytoplankton assemblage from Lake Michigan. Cultures were spiked with from c. 5 to $7 \mathrm{mg}$ $\mathrm{SiO}_{2} 1^{-1}$ as sodium metasilicate nanohydrate $\left(\mathrm{Na}_{2} \mathrm{SiO}_{3} \cdot 9 \mathrm{H}_{2} \mathrm{O}\right)$ and incubated in 3-1 capped polypropylene containers from 1 to 3 weeks. 
TABLE 1. Comparison of biogenic silica methods used in wet digestion experiments

\begin{tabular}{|c|c|c|c|c|c|c|c|}
\hline Method & Filter type & $\begin{array}{l}\text { Digestion } \\
\text { reagent }\end{array}$ & $\mathrm{pH}$ & $\begin{array}{l}\text { Milli- } \\
\text { equiv. } \\
\text { of base }\end{array}$ & $\begin{array}{l}\text { Digestion } \\
\text { conditions }\end{array}$ & $\begin{array}{l}\text { Neutralization } \\
\text { reagent }\end{array}$ & $\begin{array}{l}\text { Clean up } \\
\text { procedure }\end{array}$ \\
\hline $0.2 \mathrm{M} \mathrm{NaOH}^{*}$ & Polycarbonate $\dagger$ & $\begin{array}{l}0.2 \mathrm{M} \mathrm{NaOH} \\
4.0 \mathrm{ml}\end{array}$ & 13.3 & 0.8 & $\begin{array}{l}100^{\circ} \mathrm{C} \\
10-15 \min \end{array}$ & $\begin{array}{l}0.5 \mathrm{M} \mathrm{H}_{2} \mathrm{SO}_{4} \\
1 \mathrm{ml}\end{array}$ & None \\
\hline $\begin{array}{l}0.5 \% \mathrm{Na}_{2 .} \mathrm{CO}_{33} \ddagger \\
(0.05 \mathrm{M})\end{array}$ & Polycarbonate & $\begin{array}{l}0.5 \% \mathrm{Na}_{2} \mathrm{CO}_{3} \\
18.0 \mathrm{ml}\end{array}$ & 11.5 & 1.7 & $85^{\circ} \mathrm{C} 2 \mathrm{~h}$ & $\begin{array}{l}0.5 \mathrm{M} \mathrm{HCl} \text { to } \\
\text { turning point of } \\
\text { methyl orange }\end{array}$ & None \\
\hline $\begin{array}{l}5.0 \% \mathrm{Na}_{2} \mathrm{CO}_{3} \S \\
(0.5 \mathrm{M})\end{array}$ & Cellulose acetate & $\begin{array}{l}5.0 \% \mathrm{Na}_{2} \mathrm{CO}_{3} \\
35 \mathrm{ml}\end{array}$ & 12.0 & 32.9 & $85^{\circ} \mathrm{C} 2 \mathrm{~h}$ & $6 \mathrm{M} \mathrm{HCl} 5.5 \mathrm{ml}$ & Filtration \\
\hline
\end{tabular}

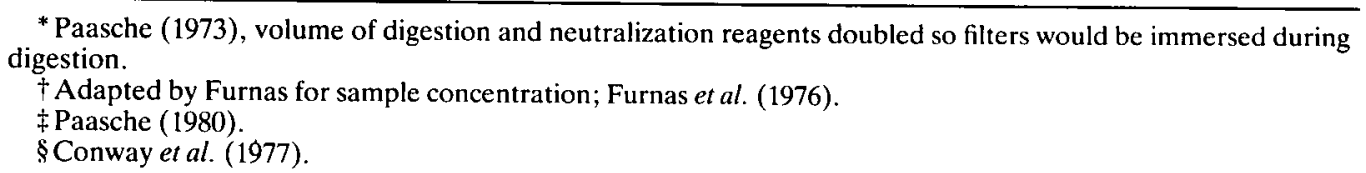

Most of the added silica was taken up by the diatoms (Table 2).

Soluble reactive silica was measured in water passed through a presoaked $47-\mathrm{mm}$ HA Millipore filter $(0.45-\mu \mathrm{m}$ pore size). Biogenic silica from $25-$ and $50-\mathrm{ml}$ well-mixed samples on two different occasions (experiments 1 and 2) was collected on 47-mm HA Millipore filters (cellulose acetate) or $47-\mathrm{mm}, 0.40-\mu \mathrm{m}$ pore size Nuclepore filters (polycarbonate) using a stainless steel filtration apparatus. Filters were stored frozen in capped, $50-\mathrm{ml}$ graduated polypropylene centrifuge tubes (Evergreen Scientific, Los Angeles, California), and digested in the same tubes. After digestion, cooling and neutralization, all samples were diluted to the $50-\mathrm{ml}$ graduation and mixed.

\section{Digestion of mineral silicates}

Large pieces of minerals (Ward's Natural Science, Rochester, New York) characteristically found in Lake Michigan surficial sediments were crushed and size fractionated (Table 3). Two size fractions, 74-63 $\mu \mathrm{m}$ and $<63 \mu \mathrm{m}$, of each mineral were isolated and dried at $110^{\circ} \mathrm{C}$ for $24 \mathrm{~h}$. For both size fractions a composite sample was prepared by mixing minerals in the relative amounts found in typical Lake Michigan surface sediment (Table 3). The total silica content of the minerals was assayed by a lithium metaborate fusion method (Medlin, Suhr \& Bodkin, 1969; Yule \& Swanson, 1969).

To determine the relative ability of the various methods to leach mineral silica, pure and composite mineral samples (approximately 2.0 $\mathrm{mg}$ ) were leached by the various methods and analysed for silica. In addition, to determine the presence of interference, replicate 200-ml water samples from Grand Traverse Bay, Lake Michigan were concentrated on Nuclepore filters and digested for various time intervals using the 0.2 $\mathrm{M} \mathrm{NaOH}$ method.

\section{Analysis of silica}

During the entire investigation samples, filter blanks (filter + reagents) and reagent blanks were analysed in triplicate and compared to a set of standards prepared in the same manner as the

TABLE 2. Initial and final soluble reactive silica concentrations in cultures. Data are averages of triplicate analyses.

\begin{tabular}{llll}
\hline Culture & Experimental set & $\begin{array}{l}\text { Initial concentration } \\
\mathrm{SiO}_{2}\left(\mathrm{mg} \mathrm{l}^{-1}\right)\end{array}$ & $\begin{array}{l}\text { Final concentration } \\
\mathrm{SiO}_{2}\left(\mathrm{mg} \mathrm{l}^{-1}\right)\end{array}$ \\
\hline Assemblage & 1 & 7.86 & 1.79 \\
Diatoma tenue & $\mathrm{I}$ & 7.43 & 0.03 \\
Fragilaria crotonensis & 1 & 7.35 & 0.01 \\
Fragilaria crotonensis & 2 & 4.74 & 0.08 \\
\hline
\end{tabular}


TABLE 3. Data on siliceous minerals characteristically found in surface sediments of Lake Michigan

\begin{tabular}{|c|c|c|c|c|}
\hline & \multicolumn{4}{|l|}{ Mineral } \\
\hline & Quartz & Clay minerals & Potassic feldspars & Sodic feldspars \\
\hline $\begin{array}{l}\% \text { Composition in } \\
\text { sediments }\end{array}$ & 61 & 7 & 6 & 6 \\
\hline Minerals used & Quartz ${ }^{\dagger}$ & Chlorite $\ddagger$ & Microcline§ & Albite** \\
\hline Chemical formula & $\mathrm{SiO}_{2}$ & $(\mathrm{Mg}, \mathrm{Al})_{12}\left[(\mathrm{Si}, \mathrm{Al})_{8} \mathrm{O}_{20}\right](\mathrm{OH})_{16}$ & $\mathrm{~K} \mathrm{Al} \mathrm{Si}_{3} \mathrm{O}_{8}$ & $\mathrm{NaAl} \mathrm{Si}{ }_{3} \mathrm{O}_{8}$ \\
\hline $\begin{array}{l}\% \mathrm{SiO}_{2} \text { calculated } \\
\% \mathrm{SiO}, \text { assayed }\end{array}$ & $\begin{array}{l}100.0 \\
100.0 \pm 1.4\end{array}$ & $\overline{33} 7+02$ & 64.8 & \\
\hline$\% \mathrm{SIO}_{2}$ assayed & $100.0 \pm 1.4$ & $33.7 \pm 0.2$ & $66.0 \pm 4.6$ & $62.0 \pm 2.0$ \\
\hline
\end{tabular}

\footnotetext{
${ }^{*}$ From Callender (1969).

† Hot Springs, Arkansas.

$\ddagger$ Calaversas Co., California.

$\S$ Parry Sound, Ontario.

** Bancroft, Ontario.
}

samples. Soluble reactive silica was measured colorimetrically at $660 \mathrm{~nm}$ on an AutoAnalyzer II using an automated version of the molybdenum blue method.

All chemicals were reagent grade. Polyware containers and implements were used for storage and handling of standards, alkaline solutions and samples.

\section{Biogenic silica in cultures}

Based on the quantities of silica assimilated by diatoms in cultures, diatom samples were quantitatively digested with all procedures (Table 4). Average recoveries of biogenic silica ranged from $98 \%$ to $102 \%$ in both sets of experiments. Precision also was good for both experimental sets. With the exception of the 25-ml Diatoma tenue sample digested with $\mathrm{NaOH}$, coefficients of variation were all less than $5 \%$ and generally less than $3 \%$.

Largest blanks resulted from the use of Millipore (cellulose acetate) and Gelman (polyvinyl chloride) filters and $\mathrm{Na}_{2} \mathrm{CO}_{3}$. Millipore filters were attacked in all digestions producing a brown-coloured suspension and fragments of partially decomposed filters. The dissolved colour remaining after post-digestion filtration gave an average blank equivalent to $0.02 \mathrm{mg} \mathrm{SiO}_{2}$ $1^{-1}(50 \mathrm{ml}$ solution $)$. Gelman $47-\mathrm{mm}(0.45-\mu$ pore size) filters were not attacked by the $0.2 \mathrm{M}$ $\mathrm{NaOH}$ digestion, however they yielded an unacceptably high blank of $1.43 \mathrm{mg} \mathrm{SiO}{ }_{2} l^{-1}(50 \mathrm{ml}$ solution). Nuclepore filters were not visibly decomposed by the alkaline digestions and produced no measurable blank (limit of detection $0.01 \mathrm{mg} \mathrm{SiO}_{2} \mathrm{I}^{-1}$ ). The $5 \% \mathrm{Na}_{2} \mathrm{CO}_{3}$ produced a reagent blank of $0.15 \mathrm{mg} \mathrm{SiO}{ }_{2} \mathrm{l}^{-1}(50 \mathrm{ml}$ solution). As expected $0.5 \% \quad \mathrm{Na}_{2} \mathrm{CO}_{3}$ yielded a proportionally lower blank. No measurable reagent blank was observed for the sodium hydroxide method.

\section{Leaching of mineral silicates}

Less than $1.5 \%$ of the silica in all mineral samples was dissolved with alkaline digestion (Fig. 1). The general order of susceptibility of selected mineral to dissolution by the various extraction methods was microcline $>$ albite $>$ chlorite $>$ quartz (Fig. 1). The order of the amount of mineral dissolution by the digestion methods was $5 \% \mathrm{Na}_{2} \mathrm{CO}_{3}>0.5 \% \mathrm{Na}_{2} \mathrm{CO}_{3}>0.2$ $\mathrm{M} \mathrm{NaOH}$, a pattern that was most apparent for the $<63 \mu \mathrm{m}$ size fraction (Fig. 1).

Time course experiments on the water collected from Grand Traverse Bay indicated that the $0.2 \mathrm{M} \mathrm{NaOH}$ digestion rapidly dissolved the biogenic silica in 11-12 min (Fig. 2). If there were any mineral silicate interference it would be leached at a constant rate during and after the dissolution of the biogenic silica. Since there appears to be no or little silica leached after 15 min this indicates that any mineral interference was insignificant compared to the quantity of biogenic silica.

\section{Discussion}

Diatom samples containing from approximately $0.2-0.4 \mathrm{mg}(3.3-6.6 \mu \mathrm{mol})$ of biogenic silica were quantitatively digested with reasonable precision by the three methods, which is consistent with 


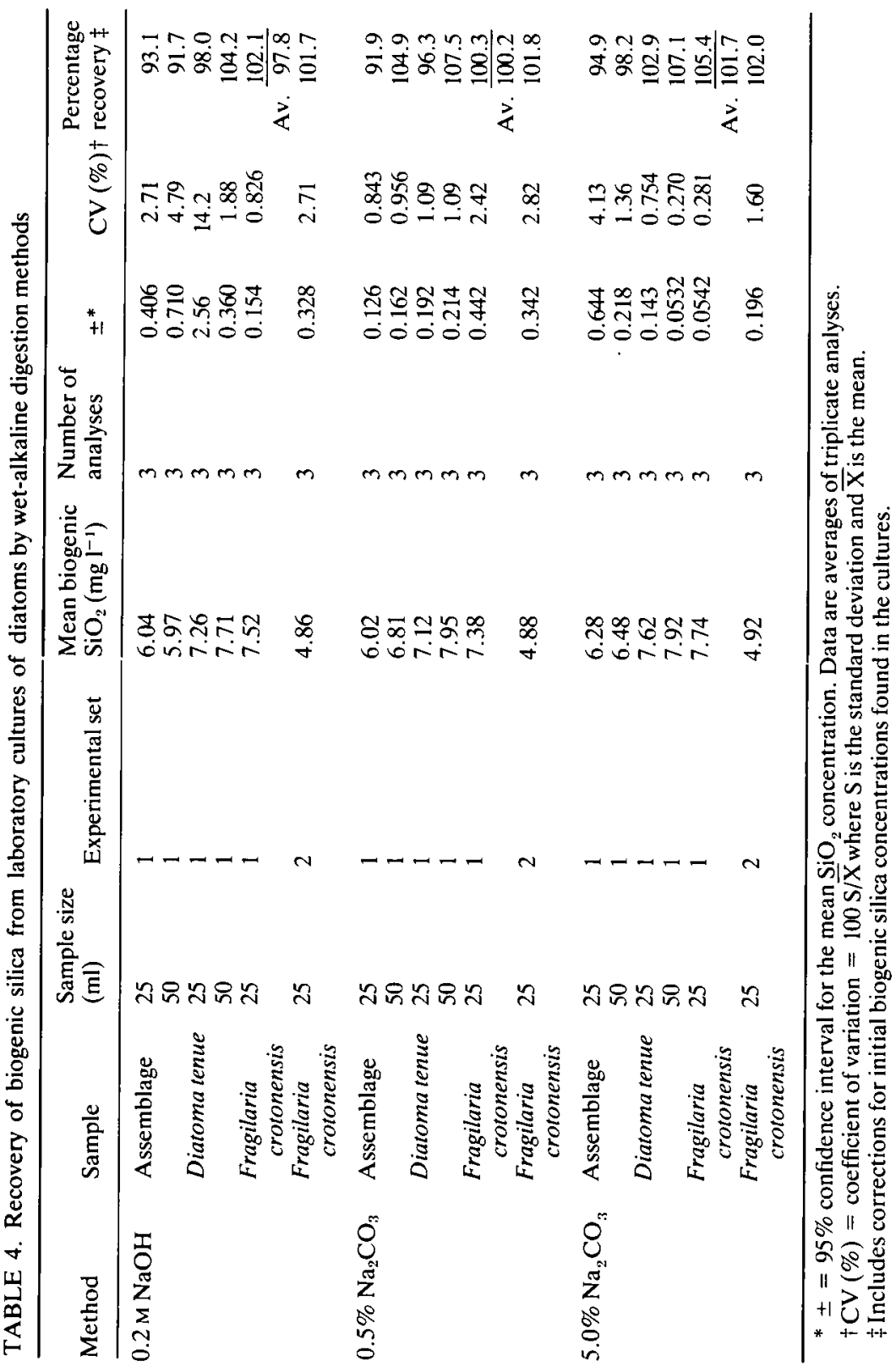




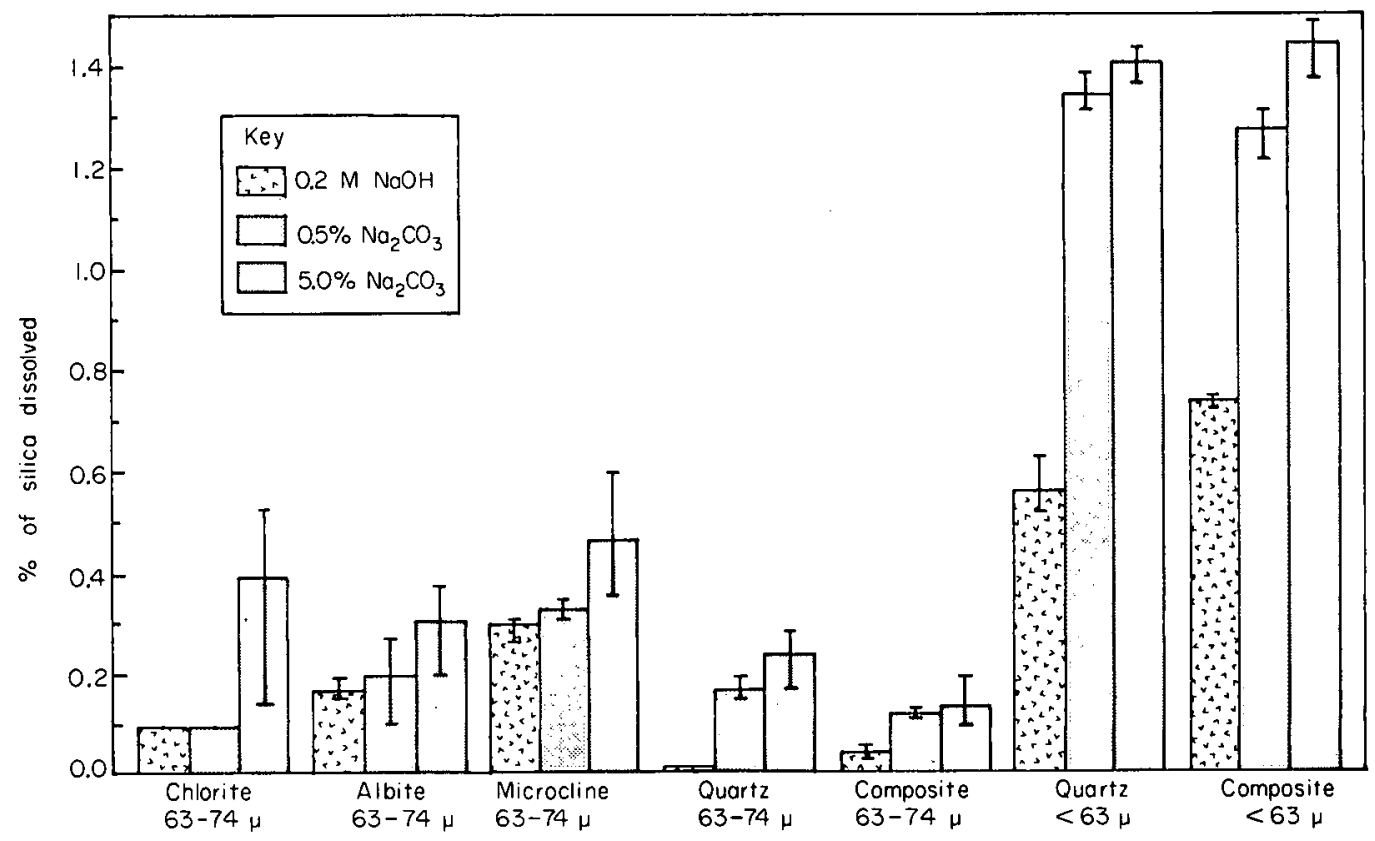

FIG. 1. Effect of wet digestion methods on dissolution of siliceous minerals.

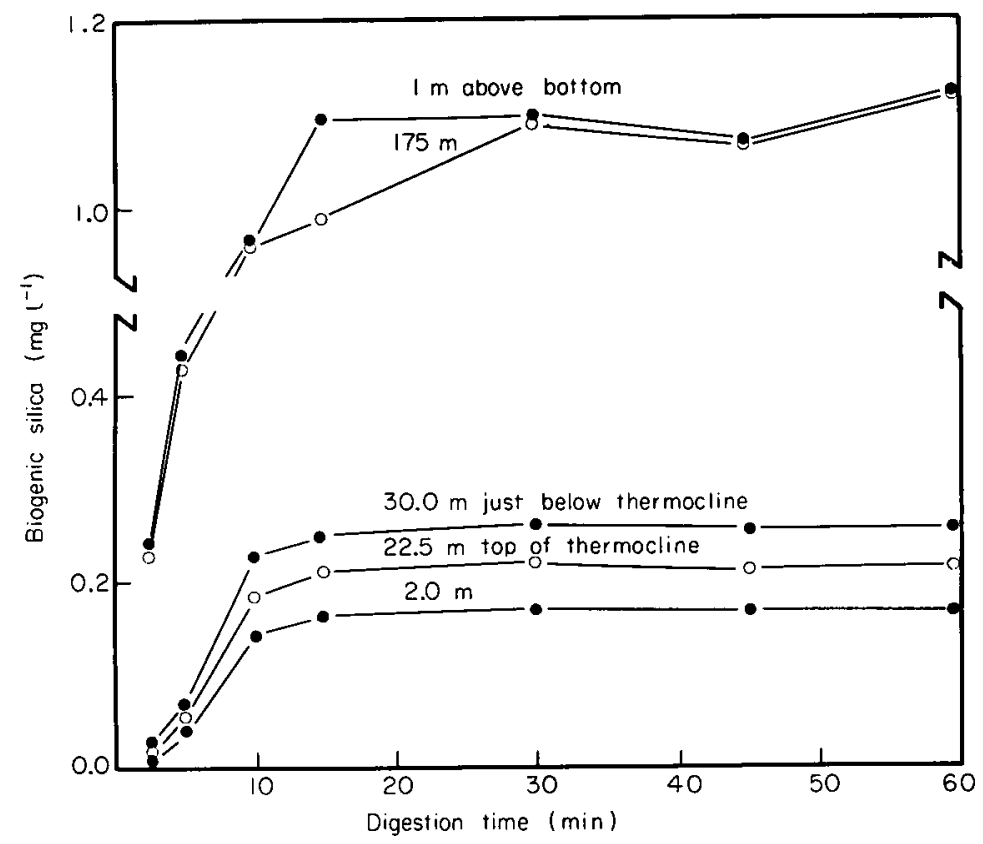

FIG. 2. Time course experiments on dissolution of biogenic silica from water samples, Grand Traverse Bay. 
results originally reported for the various techniques. Eggimann, Manheim \& Betzer (1980) reported that $0.6 \mathrm{M}$ (approx. 6\%) $\mathrm{Na}_{2} \mathrm{CO}_{3}$ was the minimum concentration of carbonate required to completely dissolve $50 \mathrm{mg}$ of silicic acid (amorphous silica) at $90-100^{\circ} \mathrm{C}$ in $2 \mathrm{~h}$. It also has been found that in leaching with $5 \% \mathrm{Na}_{2} \mathrm{CO}_{3}$ the percentage dissolved silica increased as the sample size decreased (Foster, 1953). The complete dissolution of biogenic silica by concentrations of carbonate as small as $0.5 \%$ (Table 4) may be explained by the much smaller sample size $(<0.5 \mathrm{mg})$ that was used.

Time-course experiments on Grand Traverse Bay water samples indicated that at least $90 \%$ of the sample was hydrolysed by $0.2 \mathrm{M} \mathrm{NaOH}$ method in $10 \mathrm{~min}$ and essentially $100 \%$ in $c .12$ $\min$ (Fig. 2). This is a longer time than the $10 \mathrm{~min}$ recommended by Paasche (1973) but shorter than the $15 \mathrm{~min}$ used by Werner (1966) who developed the method. Variables that affect the time required for the solution in the tubes to reach boiling such as the size of the tubes, the number of samples digested simultaneously, and variations in heating bath temperature will have an effect on dissolution rate of samples. Obviously this effect on the per cent of biogenic silica digested will be greater when using a method requiring a short digestion time than for a longer time. These variables, specifically the number of samples digested simultaneously, could easily explain the discrepency between essentially $100 \%$ recovery for the budget experiment (Table 4) and only $90 \%$ recovery for the time-course experiments in $10 \mathrm{~min}$ (Fig. 2).

Values for blanks associated with the use of cellulose acetate filters or $5 \% \mathrm{Na}_{2} \mathrm{CO}_{3}$ could introduce errors in the analysis of samples containing low amounts of biogenic silica by increasing the variance in the results and the limit of detection as described by Wilson (1961) and Roos (1962). Blanks with $\mathrm{Na}_{2} \mathrm{CO}_{3}$ leaching can be reduced by using a very pure grade reagent or by purification of the reagent by reprecipitation. Blanks can also be reduced by using filters that give a lower blank or by increasing the sample volume filtered to assure that the sample values are much greater than those of the blanks. Polycarbonate filters are recommended for sample concentration because they produce no appreciable blank. Use of these filters for concentration also eliminates time-consuming post-digestion filtration required to remove partially digested products from cellulose acetate filters. Gelman polyvinyl chloride filters were found to be grossly contaminated with silica.

In sodium carbonate procedures the $\mathrm{pH}$ must be lowered to $<4.3$ to drive off excess $\mathrm{CO}_{2}$ and eliminate interferences from bubbles in colour measurement when the acidified molybdate is added. For all the methods care must be taken to keep the $\mathrm{pH}$ above $c .1 .2$ to enable the chromophore to form. The $\mathrm{pH}$ can be adjusted by titrating to the methyl orange end point or by adding an excess amount of acid. Both techniques were tested and yielded similar results.

The amount of mineral silicate dissolved by these methods (Fig. 1) was low (1.5\% of the $\mathrm{SiO}_{2}$ content) and in the range of $<3 \%$ for chert estimated by Conway et al. (1977) and <0.5\% reported by Paasche (1980) for marine silt $(6-20$ $\mu \mathrm{m}$, c. $30 \% \mathrm{Si})$ composed mainly of illite and chlorite

Considering that $\mathrm{NaOH}$ has been reported to attack minerals to a greater extent than $\mathrm{Na}_{2} \mathrm{CO}_{3}$ (Foster, 1953; Eggimann et al., 1980; Paasche, 1980), an unexpected result of our work was that the $0.2 \mathrm{~N} \mathrm{NaOH}$ method leached less mineral silica than the carbonate methods. However, no attempt was made to study the variables that control the amount of mineral silicate leached such as digestion time, temperature and $\mathrm{pH}$ and reagent concentration and volume (Foster, 1953; Iler, 1955). The amount of interference also will depend on the type, quantity, grain size and associated surface area of the minerals. We recommend that the magnitude of mineral interference be determined on water samples by timecourse experiments. If mineral interference is present in a significant amount then instead of a single time interval digestion, time-course digestions like those used for sediment analysis should be employed (McKyes et al., 1974; Demaster, 1979).

The result of comparing methods indicates that either the $0.5 \% \mathrm{Na}_{2} \mathrm{CO}_{3}$ or the $0.2 \mathrm{M} \mathrm{NaOH}$ method can be employed for the analysis of water samples. The $5 \% \mathrm{Na}_{2} \mathrm{CO}_{3}$ method is less desirable because reagent blanks are larger than those for the other methods. We recommend that samples be concentrated on filters so that low levels of biogenic silica can be analysed. Polycarbonate filters had low reagent blanks and were not decomposed by alkaline digestion. Cellulose acetate filters were partially decomposed by leaching which produces samples that 
must be refiltered prior to colorimetric analysis. The $0.2 \mathrm{M} \mathrm{NaOH}$ method has been adapted by our laboratory for analysis of Great Lakes water samples and has also been used to digest field samples from marine as well as freshwater environments (Furnas, Hitchcock \& Smayda, 1976; Lehman, 1979).

\section{Acknowledgments}

We would like to gratefully acknowledge Dr E. Paasche, Dr H. Conway and Mr M. Furnas for their procedural information and helpful suggestions. Also we wish to thank Dr S. Kilham, Dr R. Rossmann, Mr T. Berry, Ms B. Ladewski, Mr D. Scales and $\mathrm{Mr}$ J. Sheets for their advice and/or assistance, and Dr R. Stemberger for the gift of a Fragilaria crotonensis culture. Support has been provided through Grant No. R-806294 of the U.S. Environmental Protection Agency, and the U.S. Department of Energy (COO-2003-35). This is contribution No. 334 of the Great Lakes Research Division, The University of Michigan.

\section{References}

Bailey-Watts A.E. (1976) Planktonic diatoms and some diatom-silica relations in a shallow eutrophic Scottish loch. Freshwater Biology, 6, 69-80.

Beeton A.M. \& Chandler D.C. (1963) The St. Lawrence Great Lakes. In: Limnology in North America (Ed. D. G. Frey), pp. 535-558. University of Wisconsin Press, Madison.

Busby W.F. \& Lewin J. (1967) Silicate uptake and silica shell formation by synchronously dividing cells of the diatom Navicula pelliculosa (Breb.) Hilse. Journal of Phycology, 3, 127-131.

Callender E. (1969) Geochemical characteristics of Lake Michigan and Superior sediments. Proceedings of the 12th Conference on Great Lakes, pp. 124-160. International Association of Great Lakes Research.

Chester M. \& Elderfield H. (1968) The infra-red determination of opal in siliceous deep-sea sediments. Geochimica et Cosmochimica Acta, 32, $1128-1140$.

Conway H.L., Parker J.I., Yaguchi E.M. \& Mellinger D.L. (1977) Biological utilization and regeneration of silicon in Lake Michigan. Journal of Fisheries Research Board of Canada, 34, 537-544.

Demaster D.J. (1979) The marine budgets of silica and ${ }^{\prime 2} \mathrm{Si}$. Ph.D. thesis, Yale University.

Dugdale R.C. (1972) Chemical oceonography and primary productivity in upwelling regions. Geoforum, 11, 47-61.
Eggimann D.W., Manheim F.T. \& Betzer P.R. (1980) Dissolution and analysis of amorphous silica in marine sediments. Journal of Sedimentary Petrology, 50, 215-225.

Foster M.D. (1953) Geochemical studies of clay minerals: III. The determination of free silica and free alumina in montmorillonites. Geochimica et Cosmochimica Acta, 3, 143-154.

Furnas J., Hitchcock G.L. \& Smayda T.J. (1976) Nutrient-phytoplankton relationships in Narragansett Bay during the 1974 bloom. Estuarine Processes, 1, 118-133.

Golterman H.E. (ed.) (1969) Methods for chemical analysis of fresh waters. International Biological Program Handbook 8. Blackwell Scientific Publications, Oxford.

Hurd D.C. (1973) Interactions of biogenic opal, sediment, and seawater in the Central Equatorial Pacific. Geochimica et Cosmochimica Acta, 37, 2257-2282.

Iler R.K. (1955) The Colloid Chemistry of Silica and Silicates. Cornell University Press, Ithaca, New York.

Johnson T.C. \& Eisenreich S.J. (1979) Silica in Lake Superior: mass balance considerations and a model for dynamic response to eutrophication. Geochimica et Cosmochimica Acta. 43, 77-91.

Lawson D.S., Hurd D.C. \& Pankratz H.S. (1979) Silica dissolution rates of decomposing phytoplankton assemblages at various temperatures. American Journal of Science, 27, 1373-1393.

Lehman J.T. (1979) Physical and chemical factors affecting the seasonal abundance of Asterionella formosa Hass. in a small temperate lake. Archiv für Hydrobiologie, 87, 247-303.

McKyes E., Sethi A. \& Young R.N. (1974) Amorphous coatings on particles of sensitive clay soils. Clays and Clay Minerals, 22, 427-433.

Medlin J.H., Suhr N.H. \& Bodkin J.B. (1969) A tomic absorption analysis of silicates employing $\mathrm{LiBO}_{2}$ fusion. Atomic Absorption Newsletter, 8, 25-29.

Paasche E. (1973) Silicon and the ecology of marine plankton diatoms. I. Thalassiosira pseudonana (Cyclotella nana) growth in a chemostat with silicate as limiting nutrient. Marine Biology, 19, 117-126.

Paasche E. (1980) Silicon content of five marine plankton diatom species measured with a rapid filter method. Limnology and Oceanography, 25, $474-480$.

Parker J.I, Conway H.L. \& Yaguchi E.M. (1977) Dissolution of diatom frustules and recycling of amorphous silicon in Lake Michigan. Journal of Fisheries Research Board of Canada, 34, 545-551.

Roos J.B. (1962) The limit of detection of analytical methods. Analyst, 87, 832-833.

Schelske C.L. \& Stoermer E.F. (1971) Eutrophication, silica depletion and predicted changes in algal quality in Lake Michigan. Science, 173, 423-424.

Simmons M.S. (1980) Routine determination of particulate silica in water. Analytical Letters, 13, 67-74.

Stoermer E.F. (1978) Phytoplankton assemblages as indicators of water quality in the Laurentian Great Lakes. Transactions of American Microscopical Society, 19, 1-16. 
Tessenow U. (1966) Untersuchungen über den Kieselsäuregehalt der Binnengewässer. Archiv für Hydrobiologie Supplement, 32, 1-136.

Werner D. (1966) Die Kieselsäure im Stoffwechsel von Cyclotella cryptica Reimann, Lewin and Guillard. Archiv für Mikrobiologie, 55, 278-308.

Werner D. (1977) Silicate metabolism. In: The Biology of Diatoms (Ed. D. Werner), pp. 110-149. Botanical Monographs, Vol. 13. University of California Press, Berkeley and Los Angeles.

Wilson A.L. (1961) The precision and limit of detection of analytical methods. Analyst, 86, 72-74.
Wollast R. (1974) The silica problem. In: The Sea. Ideas and Observations in the Study of the Sea (Ed. E. D. Goldberg), pp. 359-391. Marine Chemistry, Vol. 5. John Wiley and Sons, New York.

Yule J.W. \& Swanson G.A. (1969) A rapid method for decomposition and the analysis of silicates and carbonates by atomic absorption spectroscopy. Atomic Absorption Newsletter, 8, 30-33.

(Manuscript accepted 22 June 1982) 
This document is a scanned copy of a printed document. No warranty is given about the accuracy of the copy. Users should refer to the original published version of the material. 